\title{
Can Social Desirability Be Detected Statistically at the Macro-Sociological Level?
}

\author{
Walter R. Schumm, Duane W. Crawford \\ Department of Applied Human Sciences, College of Health and Human Sciences, Kansas State University, \\ Manhattan, KS 66506-1403, USA \\ Email: schumm@ksu.edu
}

\begin{abstract}
While a few have argued that social science has been subject to progressive biases, others have discounted such ideas. However, no one has yet performed empirical tests over a large range of studies for such possible bias, which we label macro-level social desirability (MLSD). Combining the results from fifty-nine empirical studies that assessed rates of nonheterosexuality among children of same-sex parents, we found that the higher the maximum rates reported, the less likely those reports were to have been cited in Google Scholar by counts or by annual rate, which may reflect MLSD. However, after several statistical controls, the association for counts became non-significant, while the association for rates became stronger, although the effect sizes were in a moderate $(\mathrm{d}=.28$ or higher $)$ to large range (d, up to .68) by either analysis. Generally, research quality acted as a suppressor variable for MLSD but was significantly related to both counts and rates of citations, indicating that higher quality articles were more likely to have been cited, even controlling for the number of years since first publication. Higher quality articles were slightly more likely to report higher rates of nonheterosexuality among children of same-sex parents. We discuss implications of our findings and suggest future directions of research.
\end{abstract}

Keywords: social desirability, citation rates, same-sex parenting, research methodology

\section{Introduction}

Stacey and Biblarz (2001) noted that Lynn Wardle (1997) had "impugned the motives, methods, and merits of social science research on lesbian and gay parenting. Wardle charged the legal profession and social scientists with an ideological bias favoring gay rights that has compromised most research in this field and the liberal judicial and policy decisions it has informed" (p. 160). However, while they disagreed with Wardle on gay rights, they did acknowledge that "We agree, however, that ideological pressures constrain intellectual development in this field." (p. 160) and that "the political stakes of this body of research are so high that the ideological 'family values' of scholars play a greater part than usual in how they design, conduct, and interpret their studies" (p. 161) regardless of which side of the fence the scholars might operate politically. Stacey and Biblarz highlighted one particular area of research, noting that "Virtually all of the published research claims to find no differences in the sexuality of children reared by lesbigay parents and those raised by nongay parents.... Yet it is difficult to conceive of a credible theory of sexual development that would not expect the adult children of lesbigay parents to display a somewhat higher incidence of homoerotic desire, behavior, or identity than children of heterosexual parents" (p. 163). Despite their attempt at being even-handed, respecting more than one side of the debate, Stacey and Biblarz (2001) were subsequently criticized sharply by other progressive scholars for their mere suggestion that the no difference hypothesis might not be completely true in all areas of same-sex parenting (Ball, 2003; Golombok et al., 2003, p. 21; Hequembourg, 2007 , p. 132; Herek, 2006, p. 613; Hicks, 2005, pp. 162-163). Ball (2003) went so far as to call Stacey and Biblarz's conclusion not only essentially unfounded but "both useless and dangerous" (p. 703). Rosky (2013) noted that "most LGBT advocates have either failed to mention the study at all, or they have glossed over the study's [Stacey \& Biblarz, 2001] controversial findings about children's sexual and gender development" (p. 677).

Whether mentioned by progressive or conservative-leaning scholars, it's one thing to claim "bias" but another entirely to demonstrate it statistically. Later, Biblarz and Stacey (2010) noted, as noted later by 
Rosky (2013, p. 677) that in one study (Bos et al., 2006), "Daughters of lesbian mothers, however, scored 0.75 SD lower on heterosexual identity than daughters of heterosexual couples" (p. 15), a possible indication that there was some association between parental and child sexual orientations, perhaps more pronounced when one or both were of a female gender. Rosky (2013) further noted that the American Psychological Association, in several amicus briefs, ignored Stacey and Biblarz (2001) and Biblarz \& Stacey's (2010) apparent findings with respect to "children's sexual identity, desire, or behavior" (p. 678). Thus, there is some degree of assertion (Biblarz \& Stacey, 2001; Rosky, 2013; Stacey \& Biblarz, 2010) that uncomfortable findings were either being ignored or sharply criticized; both approaches might have the effect of dampening enthusiasm about citing such findings, regardless of the source. Even so, Rosky treaded lightly upon the controversial ground, stating that "By acknowledging the uncertainties of this empirical debate, I do not mean to suggest that the role modeling fear has been proven correct" (p. 681). More recently Fettro and Manning (2019, p. 292) noted that a couple of researchers had found that children of same-sex parents seemed less likely to be exclusively heterosexual, but that many others had found no such relationship.

In contrast to Biblarz and Stacey's (2001) caution on the issue of second generation offspring (voices) (Kuvalanka \& Goldberg, 2009) of same-sex parents (which we are labeling 2Gen V), many scholars have strongly denied any such phenomenon. As early as 1975 Riley did so. More recently, Golombok (2015) said that $2 \mathrm{GenV}$ was "not supported by the evidence" (p. 68), which was affirmed by Patterson and Farr (2016, p. 131). Other scholars have stated that the idea of $2 \mathrm{GenV}$ was "delusional" (Ronner, 2010, p. 5) or a "myth" (Ritter, 2010, p. 384). Garwood and Lewis (2019) argued that no more than a small minority of the children of lesbigay parents would grow up to also identify as LGBTQ (p. 592). Pepping, Power, Bourne, and Lyons (2020) in their literature review concluded that decades of studies "did not suggest elevated of homosexuality among those raised by same-sex parents" (p. 302). Clearly, there have been very strong voices in the field that have discredited any idea of $2 \mathrm{GenV}$, as well as any other possible differences among children (Kim \& Stein, 2019, p. 367; Perez, 2020) which could easily encourage other scholars to cite those voices over others who might have suggested caution or even disagreement. Social pressures have continued to recent time, with many still claiming that it is an "incorrect assumption" that "same-sex parents would purposely or inadvertently make their children gay or gender variant and that this was something highly undesirable" (Park, Schmitz, \& Slauson-Blevens, 2020, p. 1798), that research has shown that the public's perception that same-sex parents would be more likely to raise nonheterosexual offspring is a "negative" - presumably incorrect - one (Park et al., p. 1803).

We think that such possible "bias" would be akin to what has been labeled "social desirability" at the individual level. Individuals may wish to present themselves in the best light to please others or to fit in with their companions or "tribe" (Clark and Winegard, 2020; Haidt, 2020). Would not it be possible that scholars might wish to present or cite research that seemed to be aligned with their heartfelt values and beliefs so they might please fellow members of the academy and fit in with their academic "tribe"/colleagues? This might represent social desirability at the macro-sociological level. Winegard and Clark insisted that sometimes scholars do "prioritize social acceptance and status attainment over truth" (p. 96), lending some credence to the possibility of macro-level social desirability.

Would it be possible to detect it, measure it, or analyze it? One attempt to detect MLSD might occur by comparing articles published by the same group of authors about the same time concerning the same sample, perhaps even in the same journal. One such natural experiment occurred with three articles published between 1979 and 1981 (Miller, Jacobsen, \& Bigner, 1981; Miller, Mucklow, Jacobsen, \& Bigner, 1980; Mucklow \& Phelan, 1979). The research team was from Colorado State University and the sample involved more than 30 lesbian and more than 30 heterosexual mothers. Two of the reports (Miller et al., 1980; Mucklow \& Phelan, 1979) were published in the same journal, Psychological Reports. Miller et al. (1980) found some results that seemed to indicate that the family backgrounds of lesbian mothers were more problematic than those of their heterosexual mothers. The other two reports found far more positive results for the lesbian mothers. As of January 2021, according to Google Scholar, Miller et al. (1980) had been cited 20 times while Miller et al. (1981) had been cited 125 times and Mucklow and Phelan (1979) 92 times. That difference is a ratio of 217 to 20, nearly 11, suggesting that scholars have preferred to cite articles that present favorable information on lesbian parents even when unfavorable information was reported by the same group of scholars from the same academic institution at about the same time. Others have taken a more recent look at that same set of articles and other 
similar sets, finding tendencies to cite more favorable articles more often than unfavorable ones (Schumm \& Crawford, 2020; Schumm, Pakaluk, \& Crawford, 2020).

However, anecdotes seldom prove much and the comparison of those three articles is hardly more than an anecdotal confirmation of the concept of scholarly social desirability at the macro-sociological level. Nevertheless, the concept of citation rates might serve as a dependent variable in an attempt to assess any such macro-level social desirability. Elsewhere, in a review of 72 reviews of the literature on same-sex parenting, we found that nearly $90 \%$ of the reviews published between 2001 and 2017 in social science outlets had concluded that there was no association between parental and child sexual orientations (Schumm \& Crawford, 2019b).

Clearly, the socially desirable answer would be that there was no association, even though a few progressive scholars have argued differently (e.g., Diamond \& Rosky, 2016; Redding, 2008; Stacey \& Biblarz, 2001). Redding (2013) argued that the firestorm generated by the Regnerus (2012a,b) study showed the public "how different standards for assessing scientific worth are applied depending upon whether a study produces results consistent with the scientists' own political views" (p. 439). Thus, the goal of Regnerus's many critics was "to marginalize" his study, if not the researcher himself (p. 441), which would ultimately lead to fewer citations, except for those critical of the study. Redding has argued that "It is human nature to frame research questions and interpret findings in ways that confirm one's political beliefs. Such biases are the norm, even among scientists" (p. 443). Redding continued and suggested that such bias may be greater among social scientists who "often have values invested in the issues they research" (p. 443). Oreskes and Conway (2011) explained that for several highly sensitive issues, such as "smoking, climate change, acid rain, ozone hole, and DDT" prominent scientists and front organizations had promoted disinformation on those topics, including influencing the scientific literature in a biased - but probably a socially desirable - way. Another way bias can influence the literature is to cite research incorrectly: to cite reviews of the literature that present mixed findings as if they favored one side entirely (e.g., Flores \& Morrison, 2021; Schumm, 2016) or ignore the larger context of research that might be less one-sided (e.g., Schumm, 2018; Schumm, 2020a, b). There are also general issues of confirmation bias (Schumm, 2021). In other words, our focus here is on only a small part of what is probably a much wider issue.

Thus, if most social scientists are progressive in their values and therefore supportive of gay rights and gay parenting, one might not be surprised if they tended to cite more often those studies whose outcomes confirmed their expectations that there would be few differences, among many possible types of outcomes, among children as a function of their parents' sexual orientations. Such social desirability might be especially strong for more controversial issues, such as whether same-sex parents are more likely to have children who grow up to be LGBT. Therefore, if such a social desirability bias did exist, there should be a modest association between the rate of LGBT outcomes among children of same-sex parents and the frequency or relative rate at which such research articles are cited by other scholars. In other words, the higher the observed rate of nonheterosexuality among the children of lesbigay parents, the less frequently such findings should be cited. However, a number of other factors might complicate that association, including the quality of research articles (presumably higher quality articles should be cited more often), and the time since the article was published (older papers should be cited more often, having had more time to have been noticed and discussed in academia). Other possible confounds would be the age of the children and the predominant gender of the children.

However, good research methodology demands that scholars attempt to discredit their own research, even before others try to do so. Thus, we agree with Winegard and Clark (2020) and with Haidt (2020) that, in search for truth, scholars should be willing, if not eager, to falsify their own hypotheses and to test alternative, competing (not just "straw man") hypotheses. There is a danger that scholars may test their ideas until the point at which the socially desirable outcome is obtained and then cease further investigation. Ideally, we should test our own initial findings as if we were our own critics.

\section{Research Hypotheses}

H1. There will be a negative association between the maximum percentage of children of LGBT parents $(\max 2 \mathrm{GenV})$ who are reported to be nonheterosexual in journal articles and the count of Google citations for the same articles. This is our test for MLSD but it is possible that applying statistical 
controls will reduce or eliminate any association. We did not make any predictions about the size of any such effect, but would prefer the guidelines of Amato (2012) who described effect sizes as " $<.20=$ weak, $.20-.39=$ moderate, $.40-.59=$ strong, and $.60+=$ very strong" (p. 772), although Funder and Ozer (2019) have recommended .10 as a very small effect, .20 as a small effect, .41 as a medium effect, .63 as a large effect, and .87 as a very large effect.

H1a. Any bivariate association between citations and max $2 \mathrm{GenV}$ may be an artifact of other factors. There are at least three possible factors that might account for any relationship between socially desirable research findings and citation rates. First, research reports might be cited more often because of their high methodological quality or, second, because of basic demographic characteristics of the studies (minimum age of the children in the study). Studies that included prepubescent children may yield low rates of any kind of sexual orientation simply because sexual orientation in general might not be a salient issue for children before puberty. Third, older studies might be cited more often because they had been in the public domain for a longer time and subject to scholarly review, which could lead to more citations. Perhaps other sample characteristics such as gender of the children might encourage scholars to cite research more often or perhaps sexual orientation (and gender, too) might be more fluid for women in general or adolescent daughters in particular (Diamond, 2008, 2020). Thus, there are several factors that might, if statistically controlled, explain away any observed bivariate association between study outcomes and citation rates.

\section{Methods}

\subsection{Sample}

Our appendix includes 60 studies, but three studies did not include a measure of $2 \mathrm{GenV}$ (Barrett \& Tasker, 2001; Gartrell et al., 2012; Lewis, 1980), and Regnerus's (2012a, b) study was not included in our analyses, reducing the number of studies to 56. However, three studies had two parts (Gartrell et al., 2011, 2019; split on gender of children, all with lesbian mothers; Lick et al., 2012; split into two separate studies, one study with 69 offspring of lesbian mothers (73\%) and gay fathers (28\%); a second study with 83 offspring of gay fathers) and those three extra samples raised the sample size to 59. We did not include studies that measured data with respect to $2 \mathrm{GenV}$ but did not report percentages (e.g., Bos et al., 2006; Bos \& Sandfort, 2010; Sarantakos, 2000; Wainright, Russell, \& Patterson, 2004). In some cases, the same results were reported in two (e.g., Bozett, 1987, 1988; Goldberg, 2007a, b; Huggins, 1989a, 1989b; Gottman, 1989; Schwartz, 1986; Tasker \& Golombok, 1995; Golombok \& Tasker, 1996) or even three different sources (Bozett, 1980, 1981a, b), but the results were counted as one data point despite being reported twice in the literature; in those cases, we used the source with the highest number of Google citations. Canning (2005) reported only the mean (14.7) and standard deviation (1.8) for the age of his children, as well as the possible range of ages, but did not report minimum/maximum ages; however, using the SPRITE program (Heathers, Anaa, van der Zee, \& Brown, 2018), we were able to determine that the actual minimum/maximum ages were 12 and 18, respectively. Swank et al. (2013) did not report the range of their children's ages but using the SPRITE program, it seemed that 16 years of age was a likely minimum. While some studies seemed promising for providing information on $2 \mathrm{GenV}$, they did not provide clear information (e.g., percentages) on the issue or provided information on gender as a function of three age groups, making it unclear which groups to use for determining the percentage of daughters in their sample (e.g., Barrett \& Tasker, 2001).

\subsection{Measures}

Variables assessed included the number of Google Scholar citations (as of 18 August 2020), the maximum percentage of nonheterosexual children (among measures of nonheterosexual attraction, behavior, or identity if more than one was available), the minimum age of the children in the study, the percentage of female children of same-sex parents in each study, and the age of the study in years prior to 2020 (e.g., $2005=15 ; 1998=22 ; 2018=2$ ) as our oldest study had been published in 1978 .

Because it was clear that the consensus scientific opinion was that same-sex parents would not have anything other than a low (e.g., $5 \%$ or less) rate of having nonheterosexual children, we used the 
maximum percentages reported, on the basis that high percentages (e.g., 50\%) should have seemed noteworthy for being "out-of-place" or "outliers". For example, in Goldberg (2007a,b), 2GenV was 17.14 $(6 / 35)$ for daughters and $14.29(1 / 7)$ for sons, so we used $17.14 \%$ as the max $2 \mathrm{GenV}$; in Murray and McClintock (2005), $2 \mathrm{GevV}$ was $47.06 \%$ (8/17) for children of lesbian or bisexual mothers and $31.58 \%$ (6/19) for children of gay or bisexual fathers, so we used $47.06 \%$ for max2GenV. Miller (1979) reported $1 / 8$ daughters and $1 / 6$ sons were lesbian/gay, so we used $16.67 \%$ for $2 \mathrm{GenV}$. Bozett (1987, 1988) reported $33.33 \%(2 / 6)$ of sons of gay fathers and $7.69 \%(1 / 13)$ of daughters were gay/lesbian, so we used $33.33 \%$ as $2 \mathrm{GenV}$. Sometimes, a maximum or minimum could be calculated but not an actual value of $2 \mathrm{GenV}$; Bowling et al. (2017) reported 23 bisexual parents with 52 children over the age of eight and nine parents having at least one nonheterosexual child, meaning that $2 \mathrm{GenV}$ could be between $17.3 \%(9 / 52)$ and $39.1 \%(9 / 23)$ or even higher if some parents had more than one nonheterosexual child. Richards et al. (2017) reported that $8.8 \%$ of the children of their 134 same-sex female parents were nonheterosexual; even though using 134 as a denominator does not permit an integer value for the numerator that will yield $8.8 \%$, we used the reported value as the best data we had, even though it failed the GRIM test (Heathers et al., 2018; however, 11/125 = 8.80 if the sample size were 125 rather than 134 as reported). We also had issues with the GRIM test with our data on max2GenV for Regnerus (2012b). Because of that issue and the fact that a substantial number of the citations for Regnerus (2012a, b) were criticisms (Bracken, 2020, p. 71), we elected to not include his study in our analyses of Google citations (hypothesis 1). We also assessed percentages of children who reported having a greater acceptance of sexual diversity for themselves, their parents (Goldberg, 2007a,b), or others for the few studies $(\mathrm{k}=9)$ that did so but we did not use that variable in our analyses. Table 1 presents the characteristics of the variables we assessed.

Table 1. Demographic and scale characteristics of the articles evaluated

\begin{tabular}{|c|c|c|c|c|c|c|}
\hline Item/Scale (N) Range (Min/Max) & $\begin{array}{l}\text { Mean } \\
(\text { or } \%)\end{array}$ & Median & $\mathrm{SD}$ & Skew & Kurtosis & $\begin{array}{l}\text { Nonnormality, } \\
\text { Overall }\end{array}$ \\
\hline $\begin{array}{l}\text { Citations of Article(s) In Google Scholar (63) } \\
(1 / 676)\end{array}$ & 100.84 & 42.0 & 140.05 & $2.30^{* *}$ & $5.54^{* *}$ & $p<.001$ \\
\hline $\begin{array}{l}\text { Rate of Citation, Articles Per year } \\
(63)(0.13 / 46.13)\end{array}$ & 6.01 & 4.40 & 7.25 & $3.14^{* *}$ & $14.43^{* *}$ & $p<.001$ \\
\hline $\begin{array}{l}\text { Maximum Percent for Children (of same-sex } \\
\text { parents) Who are Nonheterosexual (60) }(0 / 70.27)\end{array}$ & 25.51 & 23.03 & 18.27 & .426 & -.530 & $p=.200$ \\
\hline $\begin{array}{l}\text { Maximum Percent for Children (of same-sex } \\
\text { parents) Who are Open to Sexual Diversity } \\
(12)(15.38 / 84.21)\end{array}$ & 51.31 & 53.00 & 20.25 & -.242 & -0.615 & $p=.200$ \\
\hline Quality of Research Scale $(63)(1 / 10)$ & 5.71 & 5.00 & 2.08 & .273 & -.283 & $p<.001$ \\
\hline $\begin{array}{l}\text { Sample Size for LGBT Families (children)(63) } \\
(4 / 236)\end{array}$ & 39.97 & 27.00 & 39.68 & $2.80^{* *}$ & $10.19^{* *}$ & $p<.001$ \\
\hline $\begin{array}{l}\text { Sample Size for Heterosexual Families } \\
\text { (children) }(22)(11 / \sim 12,000)\end{array}$ & 818.41 & 38.50 & $2,588.1$ & $4.23^{* *}$ & $18.64^{* *}$ & $p<.001$ \\
\hline Minimum Age of children (63) $(0 / 25)$ & 15.08 & 17.00 & 5.08 & $-1.02^{*}$ & $1.47^{*}$ & $p<.001$ \\
\hline Percent of children, female (58) $(0 / 100)$ & 60.96 & 62.49 & 25.39 & $-.805^{*}$ & 0.99 & $p<.001$ \\
\hline Percent of parents, female (58) $(0 / 100)$ & 68.75 & 84.65 & 39.12 & $-0.96^{*}$ & -0.70 & $p<.001$ \\
\hline Percent of parents, male $(57)(0 / 100)$ & 31.38 & 19.00 & 38.88 & $0.98^{*}$ & -0.63 & $p<.001$ \\
\hline Years Article published Before 2020 (63)(1/42) & 17.94 & 15.00 & 12.30 & 0.51 & -0.97 & $p<.01$ \\
\hline Heterosexual Parent Comparison Group (63) & $34.92 \%$ & & & & & \\
\hline Random Sample (61) & $9.84 \%$ & & & & & \\
\hline Based on Dissertation (61) & $21.31 \%$ & & & & & \\
\hline Parent Report of Child's Sexual Orientation (61) & $22.95 \%$ & & & & & \\
\hline Child's Report of Child's Sexual Orientation (61) & $83.61 \%$ & & & & & \\
\hline
\end{tabular}

Several studies (e.g., Tasker \& Barrett, 2004; Sullins, 2015) did not report the gender of the children, as noted in Table 1. Some studies reported the gender of children for the entire sample but not for the 
subsample of children of same-sex parents (e.g., Easterbrook, 2019; Murray \& McClintock, 2005; Zweig, 1999), in which case we used the available data on gender as an approximation. When studies included transgender as part of the definition of gender (e.g., Kuvalanka \& Goldberg, 2009), we reported female/(total sample), which may underestimate the percentage of natal daughters. The percent of daughters and percent of lesbian mothers as reported in the articles correlated, $r=.186$, but the results were not significant statistically $(p<.20)$. We used the sample size associated with the number of children of same-sex parents, especially those who could identify the sexual orientation of their children, though this might differ from the number of parents interviewed or the total number of children; for example, Easterbrook (2019) interviewed 45 LGBT parents who had 95 children but only 29 of the children (genders not reported) were labeled by their parents as having a known sexual orientation, of whom 19 were nonheterosexual.

Methodological quality was measured by the sum of scores awarded for selected study characteristics (Schumm \& Crawford, 2019a). Studies that involved comparison groups, random samples, or larger sample sizes were awarded two points for each of those characteristics; one point was awarded to each study if the study explained the ages of the children clearly (minimum, average, maximum), explained parent gender clearly, explained child gender clearly, used child reports about their own sexual orientation, explained all demographic variables clearly (i.e., broke down sexual orientation as a function of the combination of child's gender and age as well as parent's gender), or included more than one sample within the same article, for a maximum score of 12 quality points. For example, a study involving one random sample (2), a comparison group (2), and a large sample (2) but did not explain the ages of the children (0) or child/parent gender (0), but did use child reports about their own sexual orientation (1) yet did not explain demographic variables clearly (0) would receive a quality score of 7 of a possible 12. Other methods of measuring article quality have been proposed (Badovinac, Riddell, Deneault, Martin, Bureau, \& O'Neill, in press) but several of their items reflect practices that should be expected of any research report (e.g., stating the research question, using valid measures, using interval/ratio outcome measures, describing demographic characteristics (i.e., gender, etc.) of the sample, describing statistical methods used, and reporting significance values), most of which were credited to the studies in their systematic review concerning attachment and psychological outcomes, with their quality scores ranging between 50 and 93 of a maximum of 100. In contrast, many of the studies cited in the Appendix did not comply with our quality items, such that total scores ranged between 1 and 10 out of a maximum of a score of 12 , even though most of our studies reviewed did state the research question, the statistical methods used, and $p$ levels obtained. The studies reviewed by Badovinac et al. (in press) did appear to be more likely to report gender characteristics of their 34 samples than were those in our selection of 60 articles.

\subsection{Analysis}

The most basic research question and hypothesis was whether citation counts would be predicted by our measure of the percentage of children of same-sex parents who reported nonheterosexual identities, for which we used regression analyses.

However, good science means being prepared to disprove your own findings by using control or moderator variables. Therefore, we used ordinary least squares regression analyses, not only to predict citations from the percentages we used but also from methodological quality, the minimum age of children in the studies, the age of the studies, and the percentage of daughters in each study. We did not go deeper into more independent variables because we wanted to keep our ratio of subjects to variables on the order of 10-1 and to avoid artificially inflated levels of explained variance that can occur as the number of variables approaches the number of cases in the analysis.

\section{Results}

Table 1 presents the measurement characteristics of the variables in the study. Quality scores ranged from 1 to 10 with a median of 5. No study scored in the possible 11 to 12 range. The distribution of our measure of $2 \mathrm{GenV}$ was not significantly non-normal, making it suitable for ordinary least squares (OLS) regression analysis. When we correlated years of publication before 2020, we found significant results for 
four variables: Google citations $(r=.459, p<.001), 2 \mathrm{GenV}(r=-.398, p<.001)$, sample size used to children of lesbigay parents $(r=-.353, p=.005)$, and minimum age of children in the studies $(r=-.413$, $p=.001$, while correlations for dissertation status, comparison studies used, random sample used, percent of daughters in the sample, percentage of lesbian mothers, percentage of gay fathers, quality scale $(\mathrm{r}=-.231, p<.07)$, and the sample size used for any heterosexual comparison group were not significant. In general, as year of publication increased from 1978, older articles were cited more often, while reported rates of $2 \mathrm{GenV}$ increased, sample sizes of children of lesbigay parents increased, and the minimum age of children of lesbigay parents tended to be older in the more recent studies.

Table 2. Regression coefficients predicting number of google citations as of august 2020 among 59 studies that measured the percentage of nonheterosexual children among children of same-sex parents

\begin{tabular}{clllll}
\hline & $\beta$ & $\beta$ & $\beta$ & $\beta$ & $\beta$ \\
\hline All Articles & & & & & \\
Maximum Percentage Nonheterosexual & $-.281^{*}$ & $-.322^{*}$ & $-.274+$ & -.153 & -.164 \\
Article Quality & ---- & .194 & .214 & $.239^{*}$ & $.232+$ \\
Min. Age of Children for each Article & ---- & ---- & -.114 & .025 & .100 \\
Years since 1978 for Article Publication & ---- & ---- & ---- & $-.490^{* * *}$ & $-.506^{* * *}$ \\
Percentage of Female Children & ---- & ---- & --- & --- & -.071 \\
Adjusted R & .063 & .084 & .077 & .262 & .249 \\
$\mathrm{~F}$ & 4.90 & 3.65 & 2.62 & 6.14 & 4.51 \\
$d f$ & 1,57 & 2,56 & 3,55 & 4,54 & 5,48 \\
$\quad p$ & .031 & .032 & .060 & $<.001$ & $=.002$ \\
\hline$+p \leq .10 * p \leq .05$ & & & & &
\end{tabular}

Note: Cohen's $d$ for the variable maximum percent heterosexual ranged from 0.31 to 0.68 , predicting the number of Google Scholar citations.

Table 3. Regression coefficients predicting annual rate of google citations as of august 2020 among 59 studies that measured the percentage of nonheterosexual children among children of same-sex parents

\begin{tabular}{|c|c|c|c|c|}
\hline & $\beta$ & $\beta$ & $\beta$ & $\beta$ \\
\hline \multicolumn{5}{|l|}{ All Articles } \\
\hline Maximum Percentage Nonheterosexual & -.140 & $-.232+$ & $-.278^{*}$ & $-.309^{*}$ \\
\hline Article Quality & ---- & $.443^{* *}$ & $.424^{* *}$ & $.433^{* *}$ \\
\hline Min. Age of Children for each Article & ---- & ---- & .108 & .201 \\
\hline Percentage of Female Children & ---- & ---- & ---- & -.062 \\
\hline Adjusted $\mathrm{R}^{2}$ & .002 & .179 & .174 & .196 \\
\hline $\mathrm{F}$ & 1.14 & 7.33 & 5.06 & 4.22 \\
\hline$d f$ & 1,57 & 2,56 & 3,55 & 4,49 \\
\hline$p$ & .290 & .001 & .004 & .005 \\
\hline
\end{tabular}

As shown in Table 2, $2 \mathrm{GenV}$ was negatively related to Google citations before adding control variables, supporting hypothesis 1 . In order to discredit our hypothesis, we added four control variables. We did not want to add more than four control variables in order to keep our ratio of sample size to variables used to less than ten. As control variables were added, we found that the statistical significance of $2 \mathrm{GenV}$ as a predictor variable decreased but remained significant until the addition of the third control variable, though it remained a weak effect size $(b=-0.153, d=0.31)$. We also predicted Google citations from linear, quadratic, and cubic terms for years of publication before 2020; while all three terms were significant, the greatest part of the variance was explained by the linear term $(.252 / .258=97.7 \%)$. We also used citations per year as a dependent variable and, as reported in Table 3 , found that the quality measure remained strong (highest $b=.443, p=.001$; lowest $b=.424, p=.001$ ) 
in equations by itself and the other two independent controls, but max $2 \mathrm{GenV}$ by itself had a smaller effect by itself $(b=-.140, d=.283, p=.290)$ but with the addition of the other variables, reaching $b=$ -.309 $(d=.649, p=.040)$ with all controls added. Thus, hypotheses $1 \mathrm{~A}$ was confirmed when using the total number of citations as the dependent variable, but it was not confirmed when using the rate of citations per year as the dependent variable. We tested for an interaction effect between $2 \mathrm{GenV}$ and article quality predicting both measures of citations but neither were significant. Badovinac et al. (in press) obtained a Pearson correlation of $r=.60(p<.001)$ between the methodological quality scale and year of publication. We found that our quality scale correlated positively with year of publication $(r$ $=.231, p<.07$ ) but not as strongly (including the Regnerus study). Quality also correlated positively with 2 GenV with $(r=.251, p=.053)$.

\section{Discussion}

With respect to our first hypothesis, in terms of apparent social desirability playing a role in citation counts, our initial results suggested "yes". Citation counts increased linearly the lower the maximum reported percentage of children of same-sex parents who were deemed LGBT. Controlling for other factors reduced the apparent impact of $2 \mathrm{GenV}$ on citation rates, yielding partial support for hypothesis $1 \mathrm{~A}$. However, when using rate of citations per year, the role of $2 \mathrm{GenV}$ increased with the addition of controls, reaching $\mathrm{b}=-.309(p=.040)$. In other words, when we controlled for article quality, the negative relationship between $2 \mathrm{GenV}$ and citations/citation rates increased. Why? Research quality was correlated positively with citations $(r=.103)$ but more strongly with citation rates $(r=.383, p=.002)$ while also being positively correlated with $2 \mathrm{GenV}(r=.208, p<, 12$, not including the Regnerus study). The effect of research quality on the $2 \mathrm{GenV} /$ Citation relationships was to contribute a positive effect that counteracted the underlying negative relationship. When that positive contribution was removed, a stronger negative relationship was left over after the suppressor effect of research quality was controlled. One background issue that we did not investigate was the political orientation of those who cited the articles; it is probable that more conservative scholars would have cited those articles with higher levels of $2 \mathrm{GenV}$ more often while more progressive scholars would have cited those articles with lower levels of 2 GenV. More politically neutral scholars may have cited both types of articles more evenly. We will leave testing that hypothesis with respect to our set of 59 articles to future research, though it has already been tested with smaller numbers of articles (Schumm \& Crawford, 2019a, b, 2020; Schumm, Pakaluk, \& Crawford, 2020).

Therefore, we think our results partially supported the concept of macro-level social desirability (MLSD). Future researchers who appreciate the concept of MLSD may tend to cite our findings with citations rates; those who don't may tend to cite our findings with respect to citation counts. The best arbiter of those two sides would be the magnitude of our effect sizes (moderate to strong). The quality of research variable generally predicted higher citations counts and rates, as would be expected. We find that role of quality of research reassuring for the future of social science.

\section{Implications}

One implication involves scientific hubris. If articles are being cited as much for their favorable findings as for their scientific quality, the academic community may be misreading the overall condition of the research literature in some areas (Schumm \& Crawford, 2019b). On the other hand, Stacey and Biblarz (2001) may have been about two decades ahead of their time, by suggesting that research literature in controversial areas could be biased. Hubris may also be reflected, for example, in literature reviews that claim to be comprehensive yet only cite a few relevant articles of the dozens that might be pertinent. We would invite readers to notify us if they can find any review of the literature on $2 \mathrm{GenV}$ that cited as many articles as studied here, as we are not yet aware of any such review. While it may not represent hubris, some scholars have published reviews of the literature that primarily cited previous reviews of the literature with little apparent exploration of primary sources (Schumm \& Crawford, 2019b). In areas involving political controversy, it may be even more risky to rely upon secondary sources without consulting primary sources. 
Second, our results show that article quality does make a substantial difference in how often articles are cited, which is reassuring for the progress of social science. Even if there is some effect of macro-level social desirability, it does not banish the importance of doing high quality research if one wants to be cited more often. Researcher should continue to strive to do the highest quality research possible within their limited resources (Bracken, 2020, pp. 62-63).

Future research could use the same data from the Appendix to this report to compare relative rates of openness to sexual diversity with rates of $2 \mathrm{GenV}$ (the former should be higher than the latter, though they should both be substantially correlated) or to predict rates of $2 \mathrm{GenV}$ from the date of publication as well as other factors, such as the percentage of daughters in the studies. Trends over time might include not only linear effects, but quadratic and cubic patterns that might be expected to increase over time, with more recent reports (e.g., Easterbrook, 2019; Gartrell et al., 2019) reporting higher 2GenV rates than reports from the 1970 s or 1980 s.

Funding: This paper received no external funding.

Conflicts of Interest: The authors declare no conflict of interest.

\section{References}

1. Amato, P. R. (2012). The well-being of children with gay and lesbian parents. Social Science Research, 41, 771-724.

2. Badovinac, S., Riddell, R. P., Deneault, A-A., Martin, J., Bureau, J-F., \& O’Neill, M. (in press). Associations between early childhood parent-child attachment and internalizing/externalizing symptoms: A systematic review and narrative synthesis. Marriage $\&$ Family Review.

3. Bailey, J., Bobrow, D., Wolfe, M., \& Mikach, S. (1995). Sexual orientation of adult sons of gay fathers. Developmental Psychology, 31, 124-129. (*)

4. Ball, C. A. (2003). Lesbian and gay families: Gender nonconformity and the implications of difference. Capital University Law Review, 31, 691-749.

5. Barrett, H., \& Tasker, F. (2001) Growing up with a gay parent: Views of 101 gay fathers on their sons' and daughters' experiences. Educational and Child Psychology, 18, 62-77. (*)

6. Bartelt, E., Bowling, J., Dodge, B., \& Bostwick, W. (2017). Bisexual identity in the context of parenthood: An exploratory qualitative study of self-identified bisexual parents in the United States. Journal of Bisexuality, 17(4), 378-399.

7. Bennett, C. S. (2001). The psychology of parenthood for the midlife lesbian mother of teens. (Doctoral dissertation, California School of Professional Psychology, Berkeley/Alameda). $\left({ }^{*}\right)$

8. Biblarz, T. J., \& Stacey, J. (2010). How does the gender of parents matter? Journal of Marriage and Family, 72, 3-22.

9. Bonander, A. R. (2016). Family communication about sex: A qualitative analysis of gay and lesbian parents' parent-child sex communication. (Doctoral dissertation, University of Nebraska, Lincoln). (*)

10. Bos, H. M. W., \& Sandfort, T. G. M. (2010). Children's gender identity in lesbian and heterosexual twoparent families. Sex Roles, 62, 114-126.

11. Bos, H. M. W., van Balen, F., Sandfort, T. G. M., \& van den Boom, D. C. (2006). Children's psychosocial adjustment and gender development in planned lesbian families. Working paper, Social and Behavioral Sciences Department of Education, University of Amsterdam.

12. Bowling, J., Dodge, B., \& Bartelt, E. (2017). Sexuality-related communications within the family context: Experiences of bisexual parents with their children in the United States of America. Sex Education, 17, 86-102. $(*)$

13. Bozett, F. W. (1980). Gay fathers: How and why they disclose their homosexuality to their children. Family Relations, 29, 173-179. (*)

14. Bozett, F. W. (1981a). Gay fathers: Evolution of the gay-father identity. American Journal of Orthopsychiatry, 51(3), 552-559 (*).

15. Bozett, F. W. (1981b). Gay fathers: Identity conflict resolution through integrative sanctioning. Alternative Lifestyles, 4(1), 90-107. (*) 
16. Bozett, F. W. (1987). Children of gay fathers. In F. W. Bozett (Ed.), Gay and lesbian parents (pp. 39-57). New York: Praeger. $(*)$

17. Bozett, F. W. (1988). Social control of identity of children of gay fathers. Western Journal of Nursing Research, 10(5), 550-565. (*)

18. Bracken, L. (2020). Same-sex parenting and the best interests principle. New York, NY: Cambridge University Press.

19. Canning, T. T. (2005). Gay and heterosexual fathers: A comparative analysis of child behavior and well-being. (Doctoral dissertation, Capella University). (*)

20. Clark, C. J., \& Winegard, B. M. (2020). Tribalism in war and peace: the nature and evolution of ideological epistemology and its significance for modern social science. Psychological Inquiry, 31(1), 1-22.

21. Diamond, L. M. (2008). Sexual fluidity. Cambridge, MA: Harvard University Press.

22. Diamond, L. M. (2020). Gender fluidity and nonbinary gender identities among children and adolescents. Child Development Perspectives, 14, 2, 110-115.

23. Diamond, L. M., \& Rosky, C. J. (2016). Scrutinizing immutability: Research on sexual orientation and U.S. legal advocacy for sexual minorities. Journal of Sex Research, 53, 363-391.

24. DiBennardo, R., \& Saguy, A. (2018). How children of LGBTQ parents negotiate courtesy stigma over the life course. Journal of International Women's Studies, 19, 290-304. (*)

25. Easterbrook, R. (2019). "This is all normal and normal is relative to you": LGBTQ+ parents' experiences discussing sex and sexuality with their children. (Master's thesis, University of Guelph, Canada). (*)

26. Fettro, M. N., \& Manning, W. D. (2019). Child well-being in same-gender-parent families: Courts, media, and social science research. In M. Y. Janning (Ed.), Contemporary parenting and parenthood: From news headlines to new research (pp. 283-301). Santa Barbara, CA.: Praeger/ABO-CLIO.

27. Flores, A. R., \& Morrison, M. (2021). Potential differences between the political attitudes of people with samesex parents and people with different-sex parents: An exploratory assessment of first-year college students. PLoS ONE, advance online.

28. Funder, D. C., \& Ozer, D. J. (2019). Evaluating effect size in psychological research: Sense and nonsense. Advances in Methods and Practices in Psychological Science, 2(2), 156-168.

29. Gartrell, N. K., Bos, H. M. W., \& Goldberg, N. G. (2011). Adolescents of the U.S. National Longitudinal Lesbian Family Study: Sexual orientation, sexual behavior, and sexual risk exposure. Archives of Sexual Behavior, 40, 1199-1209. (*)

30. Gartrell, N. K., Bos, H. M. W., \& Goldberg, N. G. (2012). New trends in same-sex sexual contact for American adolescents? Archives of Sexual Behavior, 41, 5-7. (*)

31. Gartrell, N., Bos, H. M. W., \& Koh, A. (2019). Sexual attraction, sexual identity, and same-sex sexual experiences of adult offspring in the U.S. National Longitudinal Lesbian Family Study. Archives of Sexual Behavior, 48, 1495-1503. (**)

32. Garwood, E., \& Lewis, N. M. (2019). Where are the adult children of LGBTQ parents? A critical review. Journal of Family Theory \& Review, 11(4), 592-610.

33. Goldberg, A. E. (2007a). (How) does it make a difference? Perspectives of adults with lesbian, gay, and bisexual parents. American Journal of Orthopsychiatry, 77(4), (*) 550-562.

34. Goldberg, A. E. (2007b). Talking about family: Disclosure practices of adults raised by lesbian, gay, and bisexual parents. Journal of Family Issues, 28(1), 100-131.

35. Goldberg, A. E., \& Allen, K. R. (2013a). Conclusion: Reflections on the volume and visions for the future. In A. E. Goldberg \& K. R. Allen (Eds.), LGBT-parent families: Innovations in research and implications for practice (pp. 359-365). New York, NY: Springer. $(*)$

36. Goldberg, A. E., \& Allen, K. R. (2013b). Donor, dad, or ....? Young adults with lesbian parents/ experiences with known donors. Family Process, 52, 338-350. (*)

37. Goldberg, A. E., \& Kuvalanka, K. A. (2012). Marriage (in)equality: The perspectives of adolescents and emerging adults with lesbian, gay, and bisexual parents. Journal of Marriage and Family, 74, 34-52. (*)

38. Goldberg, A. E., Kinkler, L. A., Richardson, H. B., \& Downing, J. B. (2012). On the border: Young adults with LGBTQ parents navigate LGBTQ communities. Journal of Consulting Psychology, 59, 71-85. (*)

39. Golombok, S. (2015). Modern families: Parents and children in new family forms. Cambridge, UK: Cambridge University Press.

40. Golombok, S., \& Badger, S. (2010). Children raised in mother-headed fa nmmilies from infancy: A follow-up of children of lesbian and single heterosexual mothers, at early adulthood. Human Reproduction, 25, 150-157. (*) 
41. Golombok, S., Perry, B., Burston, A., Murray, C., Mooney-Somers, J., Stevens, M., \& Golding, J. (2003). Children with lesbian parents: A community study. Developmental Psychology, 39, 20-33.

42. Golombok, S., Spencer, A., \& Rutter, M. (1983). Children in lesbian and single-parent households: Psychosexual and psychiatric appraisal. Journal of Child Psychology 63 Psychiatry, 24, 551-572. (*)

43. Golombok, S., \& Tasker, F. (1996). Do parents influence the sexual orientation of their children? Findings from a longitudinal study of lesbian families. Developmental Psychology, 32, 3-11. (*)

44. Gottlieb, A. R. (2003). Sons talk about their gay fathers: Life curves. Binghamton, NY: Harrington Park Press. $(*)$

45. Gottman, J. S. (1989). Children of gay and lesbian parents. Marriage 86 Family Review, 14(3/4), 177-196. (*)

46. Green, R. (1978). Sexual identity of 37 children raised by homosexual or transsexual parents. American Journal of Psychiatry, 135, 692-697. (*)

47. Haack-Moller, A., \& Mohl, H. (1984). Children of lesbian mothers. Dansk Psycolog Nyt, 38, 316-318. (*)

48. Haidt J. (2020). Tribalism, forbidden baserates, and the telos of social science. Psychological Inquiry, 31(1), 53-56.

49. Hays, D., \& Samuels, A. (1989). Heterosexual women's perceptions of their marriages to bisexual or homosexual men. Journal of Homosexuality, 18, 81-100. (*)

50. Heathers, J. A., Anaya, J., van der Zee, T., \& Brown, N. J. (2018). Recovering data From summary statistics: Sample parameter reconstruction via iterative Techniques (SPRITE). PeerJ Preprints, No. e26968v1.

51. Hequembourg, A. (2007). Lesbian motherhood: Stories of becoming. New York, NY: Harrington Park Press. (*)

52. Herek, G. M. (2006). Legal recognition of same-sex relationships in the United States. American Psychologist, 61, 607-621.

53. Hicks, S. (2005). Is gay parenting bad for kids? Responding to the "very idea of difference" in research on lesbian and gay parents. Sexualities, 8, 158-168.

54. Huggins, S. L. (1989a). A comparative study of self-esteem of adolescent children of divorced lesbian mothers and divorced heterosexual mothers. Journal of Homosexuality, 18(1-2), 123-135. (*)

55. Huggins, S. L. (1989b). A comparative study of self-esteem of adolescent children of divorced lesbian mothers and divorced heterosexual mothers. In F. Bozett (Ed.), Homosexuality and the family (pp. 123-135). New York, NY: Harrington Press.

56. Javaid, G. A. (1993). The children of homosexual and heterosexual single mothers. Child Psychiatry and Human Development, 23, 235-248. (*)

57. Jedzinak, J. A. (2004). Growing up in a lesbian family: A qualitative study of the adult daughter's experience. (Doctoral dissertation, Alliant International University, San Francisco, CA.). (*)

58. Joos, K. E., \& Broad, K. L. (2007). Coming out of the family closet: Stories of adult women with LGBTQ parent(s). Qualitative Sociology, 30, 275-295. (*)

59. Kim, S. A, \& Stein, E. (2019). The role of gender and gender dynamics in same-sex divorce and dissolution. In A. E. Goldberg \& A. P. Romero (Eds.), LGBTQ divorce and relationship dissolution: Psychological and legal perspectives and implications for practice (pp. 353-382). New York, NY: Oxford University Press.

60. Kuba, S. A. (1981). Being-in-a-lesbian family: The preadolescent child's experience. (Doctoral dissertation, California School of Professional Psychology, Fresno). (*)

61. Kunin, J. D. (1998). Predictors of psychosocial and behavioral adjustment of children: A study comparing children raised by lesbian parents to children raised by heterosexual parents. (Doctoral dissertation, California School of Professional Psychology, San Diego, CA.). (*)

62. Kuvalanka, K., \& Goldberg, A. E. (2009). "Second generation" voices: Queer youth with lesbian/bisexual mothers. Journal of Youth and Adolescence, 38, 904-919. (*)

63. Lavoie, S., Julien, D., \& Fortier, C. (2006). The role of affirmation of homosexual identity in the parental experience of children with a gay father or lesbian mothers. Canadian Review of Mental Health, 25, 51-65. (*)

64. Lewis, K. G. (1980). Children of lesbian parents: Their point of view. Social Work, 25, 198-203. (*)

65. Lick, D. J., Schmidt, K. M., \& Patterson, C. J. (2011). The Rainbow Families Scale (RFS): A measure of experiences among individuals with lesbian or gay parents. Journal of Applied Measurement, 12(3), 222-241. $(*)$

66. Lick, D. J., Tornello, S. L., Riskind, R. G., Schmidt, K. M., \& Patterson, C. J. (2012). Social climate for sexual minorities predicts well-being among heterosexual offspring of lesbian and gay parents. Sexuality Research and Social Policy, 9, 99-112. (**) 
67. Lick, D. J., Patterson, C. J., \& Schmidt, K. M. (2013). Recalled social experiences and current psychological adjustment among adults reared by gay and lesbian parents. Journal of GLBT Family Studies, 9(3), 230-253. $(*)$

68. Lytle, M. C., Foley, P. F., \& Aster, A. M. (2013). Adult children of gay and lesbian parents: Religion and the parent-child relationship. Counseling Psychologist, 41, 530-567. (*)

69. Macatee, T. C. (2005). Psychological adjustment of adult children raised by a gay or lesbian parent. (Doctoral dissertation, Chestnut Hill College, Philadelphia, PA.). (*)

70. Miller, B. (1979). Gay fathers and their children. Family Coordinator, 28, 544-552. (*)

71. Miller, J. A., Jacobsen, R. B., \& Bigner, J. J. (1981). The child's home environment for lesbian vs. heterosexual mothers: A neglected area of research. Journal of Homosexuality, 7, 49-56.

72. Miller, J. A., Mucklow, B. M., Jacobsen, R. B., \& Bigner, J. J. (1980). Comparison of family relationships: homosexual versus heterosexual women. Psychological Reports, 46, 1127-1132.

73. Mucklow, B. M., \& Phelan, G. K. (1979). Lesbian and traditional mothers' responses to adult response to child behavior and self-concept. Psychological Reports, 44, 880- 882.

74. Murray, P. D., \& McClintock, K. (2005). Children of the closet: A measurement of the anxiety and self-esteem of children raised by a non-disclosed homosexual or bisexual parent. Journal of Homosexuality, 49, 77-95. (*)

75. Ng, E. M. W. (1999). Adult daughters of lesbian-parent families. (Doctoral dissertation, California School of Psychology, Alameda). (*)

76. O'Connell, A. (1993). Voices from the heart: The developmental impact of a mother's lesbianism on her adolescent children. Smith College Studies in Social Work, 63(3), 281-299. (*)

77. Oreskes, N., \& Conway, E. M. (2011). Merchants of doubt: How a handful of scientists obscured the truth on issues from tobacco smoke to global warming. New York, NY: Bloomsbury Press.

78. Park, N., Schmitz, R. M., \& Slauson-Blevins, K. (2020). "It takes a lot of planning": Sexual minority young adult perceptions of gay and lesbian parenthood. Journal of Family Issues, 41(10), 1785-1809.

79. Perez, D. M. (2020). Children of same-sex parents. In T. Crosby-Cooper (Ed.), Implementing culturally responsible practices in education (pp. 230-242). Hershey, PA.: IGI Global.

80. Patterson, C. J., \& Farr, R. H. (2016). Children of lesbian and gay parents: Reflections on the research-policy interface. In K. Durkin \& H. R. Schaffer (Eds.), The Wiley handbook of developmental psychology in practice: Implementation and impact (pp. 121-142). Walden, MA.: Wiley.

81. Pattucci, A. M. L., \& Hamer, D. H. (1995). Development and familiality of sexual orientation in females. Behavior Genetics, 25, 407-420. (*)

82. Paul, J. P. (1986). Growing up with a gay, lesbian, or bisexual parent: An exploratory study of experiences and perceptions. (Doctoral dissertation, University of California, Berkeley). (*)

83. Pepping, C. A., Power, J., Bourne, A., \& Lyons. A. (2020). Lesbian, gay, bisexual, and transgender families across the globe. In K. Halford \& F. Van de Vijver (Eds.), Cross-cultural family research and practice (pp. 287-319). Cambridge, MA.: Academic Press.

84. Redding, R. E. (2008). It's really about sex: Same-sex marriage, lesbigay parenting, and the psychology of disgust. Duke Journal of Gender Law $\&$ Policy, 15, 127-193.

85. Redding, R. E. (2013). Politicized science. Society, 50, 439-446.

86. Rees, R. (1979). A comparison of children of lesbian and single heterosexual mothers on three measures of socialization. (Doctoral dissertation, California School of Professional Psychology, Berkeley, CA.). (*)

87. Regnerus, M. (2012a). How different are the adult children of parents who have same-sex Relationships? Findings from the New Family Structures Study. Social Science Research, 41, 752-770. (*)

88. Regnerus, M. (2012b). Parental same-sex relationships, family instability, and subsequent life outcomes for adult children: Answering critics of the new family structures study with additional analyses. Social Science Research, 41, 1367-1377.

89. Richards, M. A., Rothblum, E. D., Beauchaine, T. P., \& Balsam, K. F. (2017). Adult children of same-sex and heterosexual couples: Demographic "thriving". Journal of GLBT Family Studies, 13, 1-15. (*)

90. Riley, M. (1975). The avowed lesbian mother and her right to child custody: A constitutional challenge that can no longer be denied. San Diego Law Review, 12, 799-864.

91. Ritter, M. J. (2010). Perry v. Schwarzennegger: Trying same-sex marriage. The Scholar, 13, 363-393.

92. Rivers, I., Poteat, V. P., \& Noret, N. (2008). Victimization, social support, and psychological functioning among children of same-sex and opposite-sex couples in the United Kingdom. Developmental Psychology, 44, 127-124. (*) 
93. Ronner, A. D. (2010). When courts let insane delusions pass the rational basis test: The newest challenge to Florida's exclusion of homosexuals from adoption. University of Florida Journal of Law 63 Public Policy, 21, 185.

94. Rosky, C. J. (2013). Fear of the queer child. Buffalo Law Review, 61, 607-697.

95. Saffron, L. (1996). What about the children? Sons and daughters of lesbian and gay parents talk about their lives. London, UK: Cassell.

96. Saffron, L. (1998). Raising children in an age of diversity - advantages of having a lesbian mother. Journal of Lesbian Studies, 2(4), 35-47. (*)

97. Sarantakos, S. (2000). Same-sex couples. Sydney, Australia: Harvard Press.

98. Schumm, W. R. (2016). A review and critique of research on same-sex parenting and adoption. Psychological Reports, 119(3), 641-760.

99. Schumm, W. R. (2020a). Changes over the decades in selected LGBTQ research findings. JSM Sexual Medicine, 4(2), 1029, 1-8.

100. Schumm, W. R. (2020b). Avenues for future LGBT theory and research. JSM Sexual Medicine, 4(2), 1031, 1-7.

101. Schumm, W. R. (2021). Confirmation bias and methodology in social science: An editorial. Marriage \& Family Review, 57(4), 285-293.

102. Schumm, W. R., \& Crawford, D. W. (2019a). Evaluating the quality of literature reviews in social science: Developing a measure of quality with an illustration. Psychology Research and Applications, 1(2), 47-69.

103. Schumm, W. R., \& Crawford, D. W. (2019b). Scientific consensus on whether LGBTQ parents are more likely (or not) to have LGBTQ children: An analysis of 72 social science reviews of the literature published between 2001 and 2017. Journal of International Women's Studies, 20(7), 1-12.

104. Schumm, W. R., \& Crawford, D. W. (2020). Assessing citation bias in scientific literature. American Journal of Biomedical Science $\&$ Research, 10(3), 274-276.

105. Schumm, W. R., Palakuk, C. R., \& Crawford, D. W. (2020). Forty years of confirmation bias in social sciences: Two case studies of selective citations. Internal Medicine Review, 6(4), 1-14.

106. Schwartz, J. (1986). An exploration of personality traits in daughters of lesbian mothers. (Doctoral dissertation, California School of Professional Psychology, San Diego, CA.) (*, see Gottman, 1989)

107. Sirota, T. (1997). A comparison of adult attachment style dimensions between women who have gay or bisexual fathers and women who have heterosexual fathers. (Doctoral dissertation, New York University, New York, $\mathrm{NY}) .(*)$

108. Stacey, J., \& Biblarz, T. (2001). (How) does the sexual orientation of parents matter? American Sociological Review, 66, 159-183.

109. Sullins, D. P. (2015). The unexpected harm of same-sex marriage: A critical appraisal, replication, and reanalysis of Wainright and Patterson's studies of adolescents with same-sex parents. British Journal of Education, Society, \& Behavioural Science, 11(2), 1-22. (*)

110. Swank, E., Woodford, M. R., \& Lim, C. (2013). Antecedents of pro-LGBT advocacy among sexual minority and heterosexual college students. Sex Research and Social Policy, 10, 317-332. (*)

111. Tasker, F., \& Barrett, H. (2004). The sexual identity of young adult sons and daughters of gay fathers. Paper presented 12-16 May at the $7^{\text {th }}$ Congress of the European Federation of Sexology, Brighton, United Kingdom. $(*)$

112. Tasker, F., \& Golombok, S. (1995). Adults raised as children in lesbian families. American Journal of Orthopsychiatry, 65, 203-215.

113. Tornello, S. L., \& Patterson, C. J. (2016). Gay grandfathers: Intergenerational relationships and mental health. Journal of Family Psychology, 30, 543-551. (*)

114. Turner, P. H., Scadden, L., \& Harris, M. B. (1990). Parenting in gay and lesbian families. Journal of Gay 83 Lesbian Psychotherapy, 1, 55-66. (*)

115. Wainright, J. L., Russell, S. T., \& Patterson, C. J. (2004). Psychosocial adjustment, school outcomes, and romantic relationships of adolescents with same-sex parents. Child Development, 75, 1886-1898.

116. Wardle, L. D. (1997). The potential impact of homosexual parenting on children. University of Illinois Law Review, 1997, 833-919.

117. Winegard, B. M., \& Clark, C. J. (2020). Without contraries is no progression. Psychological Inquiry, 31(1), 94101.

118. Zweig, R. (1999). The relationship among psychological androgyny and the well-being of adult children of traditional and nontraditional families of origin. (Doctoral dissertation, Hofstra University, Hempstead, NY). $(*)$ 


\section{Appendix. Table of Measures for Each Source of Data}

\begin{tabular}{|c|c|c|c|c|c|c|c|c|}
\hline Authors & Date & Cites & $\mathrm{N}$ & $\begin{array}{l}\text { Minimum } \\
\text { Age }\end{array}$ & $\begin{array}{l}\text { Percent } \\
\text { Daughters }\end{array}$ & $\begin{array}{l}\text { Quality } \\
\text { Score }\end{array}$ & $\begin{array}{l}\text { Percent } \\
\text { max } 2 \mathrm{GenV}\end{array}$ & $\begin{array}{l}\text { Percent } \\
\text { Open }\end{array}$ \\
\hline Bailey et al. & 1995 & 389 & 82 & 17 & 0 & 7 & 17.07 & NA \\
\hline Barrett \& Tasker & 2001 & 114 & 54 & 1 & 49.20 & 5 & NR & 35.20 \\
\hline Bennett & 2001 & 3 & 9 & 13 & 55.56 & 5 & 20.0 & NA \\
\hline Bonander & 2016 & 2 & 14 & 14 & 64.29 & 4 & 21.43 & NA \\
\hline Bowling et al. & 2017 & 9 & $23 / 52$ & 8 & NR & 2 & 39.13 & NA \\
\hline Bozett & 1980 & 195 & 25 & 2 & NR & 1 & 0.0 & NA \\
\hline Bozett & 1987 & 179 & 19 & 14 & 68.42 & 2 & 33.33 & NA \\
\hline Bozett & 1988 & 53 & 19 & 14 & 68.42 & 4 & 15.80 & NA \\
\hline Canning & 2005 & 11 & 11 & 12 & 0 & 6 & 10.0 & 36.36 \\
\hline DiBennardo \& Saguy & 2018 & 3 & 28 & 21 & 53.57 & 6 & 39.29 & NA \\
\hline Easterbrook & 2019 & 1 & $95 / 29$ & 12 & 50.53 & 5 & 65.52 & NA \\
\hline \multirow{2}{*}{ Gartrell et al. } & $2011 / 1$ & 146 & 37 & 17 & 0 & 10 & 21.62 & NA \\
\hline & $2011 / 2$ & 146 & 37 & 17 & 100.00 & 10 & 48.65 & NA \\
\hline Gartrell et al. & 2012 & 40 & 78 & 17 & 50.00 & 9 & NA & 15.38 \\
\hline \multirow[t]{2}{*}{ Gartrell et al. } & $2019 / 1$ & 9 & 39 & 25 & 0 & 9 & 33.33 & $\mathrm{NA}$ \\
\hline & $2019 / 2$ & 9 & 37 & 25 & 100.00 & 9 & 70.27 & NA \\
\hline Goldberg & $2007 a$ & 137 & 42 & 19 & 83.33 & 7 & 17.14 & 50.00 \\
\hline \multirow{2}{*}{ Goldberg \& Allen } & $2013 \mathrm{a}$ & 62 & 20 & 15 & 80.00 & 3 & 15.00 & NA \\
\hline & $2013 b$ & 9 & 11 & 19 & 72.73 & 3 & 27.27 & NA \\
\hline Goldberg \& Kuvalanka & 2012 & 69 & 49 & 14 & 77.55 & 5 & 20.41 & NA \\
\hline Goldberg et al. & 2012 & 40 & 41 & 18 & 80.49 & 5 & 21.95 & NA \\
\hline Golombok \& Badger & 2010 & 175 & 14 & 16 & 50.00 & 6 & 7.14 & NA \\
\hline Golombok et al. & 1983 & 676 & $27 / 9$ & 5 & 64.86 & 7 & 11.11 & NA \\
\hline Golombok \& Tasker & 1996 & 524 & 25 & 23 & 68.00 & 7 & 36.00 & 56.00 \\
\hline Gottlieb & 2003 & 19 & 12 & 13 & 0 & 5 & 33.33 & NA \\
\hline Gottman & 1989 & 327 & 35 & 18 & 100.00 & 9 & 25.71 & NA \\
\hline Green & 1978 & 513 & 4 & 11 & 25.00 & 5 & 0.0 & NA \\
\hline Haack-Moller \& Mohl & 1984 & 8 & 13 & 14 & 53.85 & 3 & 7.69 & NA \\
\hline Hays \& Samuels & 1989 & 88 & 26 & 16 & NR & 3 & 11.54 & NA \\
\hline Hequembourg & 2007 & 59 & 56 & 0 & 51.79 & 6 & 21.43 & NA \\
\hline Huggins & 1989 & 258 & 18 & 13 & 50.00 & 5 & 0.0 & NA \\
\hline Javaid & 1993 & 80 & $26 / 11$ & 6 & 42.31 & 9 & 27.27 & 63.64 \\
\hline Jedzinak & 2004 & 5 & 7 & 18 & 100.00 & 5 & 42.86 & 71.43 \\
\hline Joos \& Broad & 2007 & 29 & 26 & 18 & 100.00 & 6 & 42.31 & NA \\
\hline Kuba & 1981 & 8 & 10 & 8 & 70.00 & 5 & 0.0 & NA \\
\hline Kunin & 1998 & 18 & 47 & 12 & 51.06 & 8 & 21.28 & 44.68 \\
\hline Kuvalanka \& Goldberg & 2009 & 88 & $32 / 18$ & 18 & 72.22 & 6 & 40.63 & NA \\
\hline Lavoie et al. & 2006 & 9 & 20 & 18 & 60.00 & 4 & 50.0 & NA \\
\hline Lewis & 1980 & 176 & 21 & 9 & 52.38 & 4 & NA & 38.10 \\
\hline Lick et al. & 2011 & 12 & 91 & 18 & 75.00 & 5 & 39.56 & NA \\
\hline \multirow[t]{2}{*}{ Lick et al. } & $2012 / 1$ & 66 & 69 & 18 & 72.46 & 7 & 46.38 & NA \\
\hline & $2012 / 2$ & 66 & 70 & 18 & 69.88 & 7 & 22.86 & NA \\
\hline Lick et al. & 2013 & 35 & 87 & 18 & 74.73 & 5 & 40.23 & NA \\
\hline Lytle et al. & 2013 & 19 & 10 & 19 & 80.00 & 5 & 50.0 & NA \\
\hline Macatee & 2005 & 2 & 17 & 18 & 82.35 & 4 & 5.88 & NA \\
\hline Miller & 1979 & 245 & 14 & 14 & 57.14 & 4 & 14.29 & NA \\
\hline Murray \& McClintock & 2005 & 34 & $36 / 17$ & 18 & 73.74 & 8 & 47.06 & NA \\
\hline $\mathrm{Ng}$ & 1999 & 6 & 6 & 21 & 100.00 & 5 & 50.00 & NA \\
\hline O'Connell & 1993 & 106 & $11 / 6$ & 16 & 54.55 & 5 & 16.67 & NA \\
\hline Pattucci \& Hamer & 1995 & 170 & $31 / 19$ & 18 & 61.29 & 4 & 31.58 & NA \\
\hline
\end{tabular}




\begin{tabular}{lllllllll}
\hline Authors & Date & Cites & $\mathrm{N}$ & $\begin{array}{l}\text { Minimum } \\
\text { Age }\end{array}$ & $\begin{array}{l}\text { Percent } \\
\text { Daughters }\end{array}$ & $\begin{array}{l}\text { Quality } \\
\text { Score }\end{array}$ & $\begin{array}{l}\text { Percent } \\
\text { max2GenV }\end{array}$ & $\begin{array}{l}\text { Percent } \\
\text { Open }\end{array}$ \\
\hline Paul & 1986 & 62 & $34 / 19$ & 18 & 55.88 & 6 & 68.42 & 84.21 \\
Rees & 1979 & 42 & 12 & 10 & 58.33 & 7 & 0.0 & NA \\
Regnerus & 2012 & 369 & $236 / 90$ & 18 & 50.85 & 10 & 55.56 & NA \\
Richards et al. & 2017 & 16 & $147 / 134$ & 18 & 45.52 & 7 & 8.80 & NA \\
Rivers et al. & 2008 & 121 & 18 & 12 & 44.44 & 8 & 5.56 & NA \\
Saffron & 1996 & 79 & 15 & 17 & 73.33 & 5 & 46.67 & 75.00 \\
Sirota & 1997 & 15 & 67 & 18 & 100.00 & 9 & 34.33 & 69.77 \\
Sullins & 2015 & 25 & 20 & 12 & NR & 5 & 23.20 & NA \\
Swank et al. & 2013 & 39 & 168 & 16 & 63.69 & 5 & 30.95 & NA \\
Tasker \& Barrett & 2004 & 6 & 36 & 18 & NR & 6 & 16.67 & NA \\
Tornello \& Patterson & 2016 & 17 & 79 & 18 & 50.63 & 4 & 6.33 & NA \\
Turner et al. & 1990 & 107 & $21 / 12$ & 12 & 52.38 & 3 & 16.67 & NA \\
Zweig & 1999 & 8 & $242 / 80$ & 17 & 73.97 & 6 & 57.50 & NA \\
\hline
\end{tabular}

